\title{
nature
}

\section{Financial flexibility the key to Germany's scientific prosperity}

Ten years after the fall of the Berlin Wall, and despite a traumatic transition, science in east Germany is flourishing. Nationwide obstacles to progress require increased federal leverage for their removal.

A glance across Central and Eastern Europe quickly reveals how well east German science has done since the Berlin Wall fell ten years ago. Without the generous subsidies from the German federal government after reunification and the tough imposition of Western standards of research, east German research institutes and universities would probably be in the same stagnant state as most of the cash-starved research institutes further east. Instead, many are in a position to compete with the best in the world.

But there was pain and also significant cost in the transition (see Briefing, page 635), including the loss of the exceptionally high quality of teaching in the east German university system. And not all of the many dismissals were fair. But now the need must be to provide healthy and, especially, flexible funding for science in the east as well as the west of the country, based on assessments of quality that can no longer be so predominantly focused on the east-west axis.

The high financial cost of the absorption of east German research has already begun a much-needed shake-up in the west German system, where scientists found themselves facing unfamiliar funding cuts in the 1990s, and under consequent pressure to submit to evaluations of their work and institutes, just as their eastern colleagues had to do.

The evaluation fever now raging through German science will benefit both east and west. Every publicly funded research institute and national research centre has undergone, or is going through, well-organized external evaluations based on widely accepted criteria. Even the major research organizations are being evaluated to check that their distribution of funds is as efficient as possible. The Wissenschaftsrat, Germany's science council, will integrate the results in a report on the entire research landscape next summer. Research minister Edelgard Buhlman must then decide what steps to take to improve the operation of the research system as a whole.
To bring this shake-up to its logical conclusion, the eye-glazing and overly complex arrangements of financing must be addressed. The current system, under which research organizations are jointly financed by federal and Länder (state) governments, is so inflexible that it is almost impossible to shift funds from one organization to another, or even within an organization. This is not least because the proportions of contributions of the partners vary enormously. For example, the federal government foots 90 per cent of the bills from the national research centres and the applied research institutes of the Fraunhofer Society, but only 50 per cent of those from the Max Planck Society and the Leibniz Society. Although an evaluation in the early 1990s recommended the break-up of one national research centre into smaller units that would be transferred to the Fraunhofer Society or the Leibniz Society, existing financing mechanisms have so far blocked the change.

The research ministry is keen to simplify the system, but cannot do so independently of the more general and even more complex system of tax redistribution (Finanzausgleich) between Länder, in which rich Länder must redistribute a proportion of their federal receipts to poorer Länder. The highly sensitive Finanzausgleich mechanisms are currently being discussed at government level, so this is exactly the time to broach the issue of a single financing mode for research organizations.

Most German science policy experts believe that a 50/50 split between federal and Länder governments across the board would be the right way forward. This would ensure an even balance of political influence over individual research institutes, and it fits well with traditional German consensus-seeking policies. However, given the need for tough decisions to be made quickly, it would be wiser to push for a split — say $60 / 40$ — that would introduce a power balance in favour of the federal government while still leaving a reasonable level of influence for the Länder.

\section{Caution: traditional knowledge}

\section{Principles of merit need to be spelt out in distinguishing valuable knowledge from myth.}

W hat makes knowledge 'scientific', and thus distinguishable from other forms? This question has a relevance well beyond the philosophical, with the scientific nature of data having an increasing significance in issues ranging from the reproducibility of discoveries for which patents are being applied, to the argument that environmental regulations should be based on 'sound science'.

The question also overshadows the growing recognition that 'traditional knowledge', such as folk remedies for illnesses, deserves greater respect from modern science than it often receives. But such acceptance also requires due caution, and a rigorous assessment of more and less deserving forms of traditional knowledge.

That critically minded agenda may now be about to be established. Member organizations of what was previously known as the International Council of Scientific Unions (ICSU) have made clear their reservations about an open-ended endorsement of traditional knowledge systems. At their general assembly in Cairo last month, they asked ICSU to carry out a "critical study" of the idea of traditional knowledge, concerned at the all-embracing interpretations that might be made of the concept, and particularly the support it might be taken to give to ideas such as astrology and creationism (see page 631).

The task should not be approached naively. Superficially attractive solutions to distinguishing between forms of knowledge, such as dismissing some knowledge systems (like astrology) on the grounds of non-reproducibility, could also rule out valid scientific ideas (such as natural evolution). But a clear statement of the practical principles on which scientific knowledge is based would be widely welcomed, especially if it also helps those battling with anti-scientific dogmas in both developed and developing countries. ICSU has yet to demonstrate its ability to live up to its new title, the International Council for Science. This is an opportunity for it to do so. 